(D) Check for updates

Cite this: Food Funct., 2018, 9, 5629

\title{
Nutritional characterization and shelf-life of packaged microgreens
}

\author{
Vito Michele Paradiso, (D)*a Maria Castellino, ${ }^{a}$ Massimiliano Renna, \\ Concetta Eliana Gattullo, (iD a Maria Calasso, (D) ${ }^{a}$ Roberto Terzano, (D) ${ }^{a}$ \\ Ignazio Allegretta, (D) ${ }^{a}$ Beniamino Leoni, ${ }^{b}$ Francesco Caponio (D) $^{a}$ and \\ Pietro Santamaria (iD ${ }^{b}$
}

Besides the variety of colours and flavours, microgreens show interesting nutritional properties, mainly regarding their contents of mineral nutrients and bioactive compounds. To date, the literature has prevalently focused on the individual nutritional features of microgreens usually belonging to Brassicaceae. The present study reports an articulated nutritional profile of six genotypes of microgreens, belonging to three species and two families: chicory (Cichorium intybus L., Puglia's local variety 'Molfetta', CM, and cultivar 'Italico a costa rossa', CR) and lettuce (Lactuca sativa L. Group crispa, cultivar 'Bionda da taglio', LB, and 'Trocadero', LT), from Asteraceae; and broccoli (Brassica oleracea L. Group italica Plenk, Puglia's local variety 'Mugnuli', BM, and cultivar 'Natalino', BN) from Brassicaceae. All the microgreens, except LB, can be considered good sources of $\mathrm{Ca}$, whilst LT and CM also showed considerable amounts of $\mathrm{K}$. As regards bioactive compounds, Brassica microgreens were the richest in phenolic antioxidants. The microgreens also presented higher amounts of $\alpha$-tocopherol and carotenoids compared to mature vegetables. In particular, broccoli microgreens and LB showed the highest amounts of vitamin E, while Asteraceae microgreens presented the highest levels of carotenoids. Due to their delicate tissues, fresh cut microgreens showed a shelf life not exceeding ten days at $5{ }^{\circ} \mathrm{C}$. The results obtained highlight the possibility to exploit genetic biodiversity in order to obtain tailored microgreens with the desired nutritional profiles, with particular regard to mineral nutrients and bioactive compounds. Appropriate pre- and post-harvest strategies should be developed, so as to allow microgreens to retain as long as possible their nutritional value.

Received 13th June 2018 Accepted 19th July 2018 DOI: $10.1039 / \mathrm{c} 8 \mathrm{fo} 01182 \mathrm{f}$ rsc.li/food-function vegetables, ${ }^{9}$ and such levels were unaffected by changes in soil properties and composition. Brassicaceae microgreens were also reported as good sources of $\mathrm{K}, \mathrm{Ca}, \mathrm{Fe}$ and $\mathrm{Zn} .{ }^{10}$ No further data are available, to the best of our knowledge, on the mineral content of other microgreens.

Vitamins and their precursors are another nutrient class lending nutritional value to microgreens. Relevant amounts of $\alpha$-tocopherol (vitamin E), $\beta$-carotene (pro-vitamin A), ascorbic acid (vitamin $\mathrm{C}$ ) and phylloquinone (vitamin $\mathrm{K}_{1}$ ) were reported in recent investigations, though high variability was observed when different species and cultivars were compared.,11-13 Other phytochemicals reported in microgreens are phenolic antioxidants, anthocyanins, glucosinolates and carotenoids. $^{7,12-15}$

Due to their favourable contents in micronutrients and bioactive compounds, microgreens have been proposed as "super foods", 6,16 and have been suggested for very demanding consumers, such as raw foodists, vegetarians and vegans. ${ }^{4}$ They are also indicated for growing in urban and peri-urban settings, and have been proposed even as a component of space life support systems. ${ }^{2,17}$

\footnotetext{
${ }^{a}$ Department of Soil, Plant and Food Science, University of Bari Aldo Moro, Via Amendola 165/a, 70126 Bari, Italy. E-mail: vito.paradiso@uniba.it; Tel: +39 (0)80 5442272

${ }^{b}$ Department of Agricultural and Environmental Science, University of Bari Aldo Moro, Via Amendola 165/a, 70126 Bari, Italy
} 
Surprisingly, very scarce information is available in the literature regarding the proximate composition of microgreens. ${ }^{4,18}$

As fresh-cut products, microgreens are characterized by a relatively short shelf-life, not exceeding 10-14 days. ${ }^{2}$ Being composed of young tissues, fresh-cut microgreens are highly respiring products, whose decline is related to a stress induced response more than to natural senescence. ${ }^{2}$ Both pre-harvest and post-harvest treatments, as well as different packaging materials and modified atmosphere packaging (MAP), have been considered as variables affecting the shelf-life of freshcut microgreens. ${ }^{13,14,19-22}$ Calcium application in preharvest improved the overall and microbial quality of broccoli microgreens during storage at $5{ }^{\circ} \mathrm{C} .{ }^{14,20,21}$ Different sanitizers were also compared for post-harvest treatments, with varying results. Kou et $a .^{23}$ improved the microbial quality of buckwheat microgreens by washing with chlorine; an analogous effect was observed by Xiao et $a l^{22}$ for radish microgreens. Calcium lactate in the chlorinated dipping solution provided further improvement of the shelf-life of broccoli microgreens, though the longest shelf-life was obtained with calcium preharvest treatments without dipping. ${ }^{21}$ Chandra et $a .^{19}$ obtained the best microbial quality on Tah Tasai Chinese cabbage microgreens combining washing in citric acid solution with ethanol spray. The film oxygen transmission rate affected the equilibrium concentrations of $\mathrm{CO}_{2}$ and $\mathrm{O}_{2}$, but did not generate major effects on the shelf life of the product. $^{22,23}$ Nevertheless, storage temperature is the most influencing factor on the product shelf-life..$^{2,22}$

The present study was aimed to evaluate the nutritional potential of six microgreens, belonging to three species (Cichorium intybus L., Brassica oleracea L. Group italica Plenk, and Lactuca sativa L. Group crispa), including two Italian local varieties, by integrating different compositional aspects and providing a nutritional profile. Three out of the six microgreens were also packed as fresh cut produce and subjected to shelf-life evaluation at refrigerated temperature.

\section{Materials and methods}

\subsection{Microgreen production and storage}

Six genotypes of microgreens were grown: two of Cichorium intybus L. (Puglia's local variety 'Molfetta', CM, and cultivar 'Italico a costa rossa', CR), two of Lactuca sativa L. Group crispa (cultivar 'Bionda da taglio', LB, and 'Trocadero', LT) and two of Brassica oleracea L. Group italica Plenk (Puglia's local variety 'Mugnuli', BM, and cultivar 'Natalino', BN). All cultivar seeds were purchased from Riccardo Larosa (Andria, Italy), while for the local varieties, seeds produced by Puglia's hold-farmers were used. The six genotypes were sown in plastic trays (with holes at the bottom) filled with a mixture of peat (50\% white$50 \%$ black peat mixture, Brill 3 Special, Brill Substrates, Georgsdorf, Germany). For the genotypes of $C$. intybus and L. sativa a sow density of 3 seeds per $\mathrm{cm}^{2}$ was used, while for the $B$. oleracea genotypes a sow density of 4 seeds per $\mathrm{cm}^{2}$ was used. The microgreens were grown in a growth chamber at con- trolled temperature $\left(20^{\circ} \mathrm{C}\right)$ and relative humidity (85\%). During the first two days, the trays were covered, and the seeds were germinated in the dark. After germination, the seedlings were exposed to a light irradiance of $200 \mu \mathrm{mol} \mathrm{m} \mathrm{m}^{-2} \mathrm{~s}^{-1}$, determined by using LICOR LI-190 (Li-Cor Inc., USA) quantum sensors, for a $12 \mathrm{~h}$ photoperiod. The seedlings were fertigated daily using a nutrient solution containing all the essential macro- and micro-nutrients with the following concentrations expressed in $\mathrm{mg} \mathrm{L}^{-1}$ : N 105, P 15, K 117, Ca 100, Mg 24, B 0.25, Cu 0.01, Fe 2.5, Mn 0.25, Zn 0.025, and Mo 0.005. ${ }^{1}$ Twelve-day-old microgreens were harvested by cutting the stem ends with scissors. The harvested microgreens were weighed to determine the shoot fresh weight $(\mathrm{FW})$ per unit area $(n \geq 7)$.

\subsection{Microgreen packaging and storage}

Three out of the six genotypes, one per species (i.e. Cichorium intybus L. (cultivar 'Italico a costa rossa', CR); Lactuca sativa L. Group crispa (cultivar 'Bionda da taglio', LB); and Brassica oleracea L. Group italica Plenk (cultivar 'Natalino', BN), were packed as fresh cut vegetables. The fresh cut microgreens were washed in pre-disinfected mesh bags with gentle agitation in $20 \mathrm{~L}$ wash solutions $\left(100 \mathrm{mg} \mathrm{L}^{-1} \mathrm{NaOCl}\right)$ at $10^{\circ} \mathrm{C}$ for $1 \mathrm{~min}$, followed by rinsing with $10^{\circ} \mathrm{C}$ tap water for $1 \mathrm{~min}$. The washed microgreens were then gently dried for $3 \mathrm{~min}$ with a commercial salad centrifugal dryer to remove excess surface water. The microgreens were then packed $(25 \mathrm{~g})$ in polypropylene bags $\left(15 \times 20 \mathrm{~cm}\right.$, OTR $25{ }^{\circ} \mathrm{C}, 0 \% \mathrm{RH}=1800 \mathrm{~cm}^{3} \mathrm{~m}^{-2} 24 \mathrm{~h}^{-1}$, WVTR $38{ }^{\circ} \mathrm{C}, 90 \% \mathrm{RH}=6 \mathrm{~g} \mathrm{~m}^{-2} 24 \mathrm{~h}^{-1}$ ) and stored at $5^{\circ} \mathrm{C}$ in a climate chamber (Memmert Incubator, Memmert GmbH, Schwabach, Germany) for ten days. Sampling was performed after 3, 7 and 10 days of storage. Three packs were sampled at each time and analysed as independent replicates for shelf-life evaluation.

\subsection{Proximate composition}

The harvested microgreens were subdivided into two fractions. The first fraction was immediately used for the analyses requiring fresh samples. The other sub-samples were freeze-dried (ScanVac CoolSafe 55-9 Pro; LaboGene ApS, Lynge, Denmark) and then used for the analyses requiring lyophilized samples. The dry matter (DM) concentration was measured with an automatic moisture analyzer (Mod. MAC 110/NP, Radwag Wagi Elektroniczne, Radom, Poland) at $105^{\circ} \mathrm{C}$. The proximate composition of the samples was analyzed as follows: ashes were determined by using a muffle furnace according to AOAC method $923.03 ;^{24}$ protein content $(\mathrm{N} \times 6.25)$ was determined by the Kjeldahl nitrogen method according to AOAC method 955.04; ${ }^{24}$ fat content was determined after Soxhlet extraction according to AOAC method $920.39 ;^{24}$ dietary fiber content was determined by an enzymatic-gravimetric procedure according to AOAC method $991.43 ;^{24}$ sucrose, fructose and glucose were determined by an enzymatic assay (K-SUFRG, Megazyme, USA); total carbohydrates were calculated by the difference of protein, lipid and ash on a dry matter basis. Dry matter, total lipids and ashes were determined on quadruplicate samples, and proteins and sugars were assessed on duplicate samples. 


\subsection{Mineral content}

The freeze-dried microgreen samples were powdered using a vibromilling system (MM 400, Retsch GmbH, Haan, Germany). An aliquot of $100 \mathrm{mg}$ of sample powder was suspended in $5 \mathrm{~mL}$ of Triton X-100 (Sigma-Aldrich) and added in $10 \mu \mathrm{L}$ of Ga solution $\left(1000 \mathrm{mg} \mathrm{L}^{-1}\right)$, the latter used as an internal standard. The suspensions were vortexed and placed in an ultrasonic bath for $15 \mathrm{~min}$; then $10 \mu \mathrm{L}$ of each suspension was placed on a TXRF quartz reflector and dried at $50{ }^{\circ} \mathrm{C}$ under a laminar fumehood. Macroelement ( $\mathrm{P}, \mathrm{K}, \mathrm{Ca}$ and $\mathrm{S}$ ) and microelement (Fe, $\mathrm{Zn}, \mathrm{Mn}, \mathrm{Cu}$ and $\mathrm{Ni}$ ) concentrations in the microgreen suspensions were determined by using a total reflection X-ray fluorescence spectrometer (TXRF; S2 Picofox, Bruker Nano $\mathrm{GmbH}$, Berlin, Germany), equipped with a Mo source $(50 \mathrm{kV}$, $600 \mu \mathrm{A})$. The TXRF spectra were obtained with $1000 \mathrm{~s}$ live time. The concentrations of $\mathrm{Na}, \mathrm{Mg}, \mathrm{Cd}$ and $\mathrm{Pb}$ were determined by inductively coupled plasma-atomic emission spectrometry (ICP-AES; Thermo iCAP 6000 series, Thermo Fisher Scientific Inc., Waltham, MA, USA). For this purpose, an aliquot of $150 \mathrm{mg}$ of powdered microgreens was digested with $7 \mathrm{~mL}$ $\mathrm{HNO}_{3}(69.0 \%)$ and $1 \mathrm{~mL} \mathrm{H} \mathrm{O}_{2}$ (30\%) (TraceSELECT®, trace analysis reagents, Sigma Aldrich) using a microwave digestion system (Multiwave GO, Anton Paar, Graz, Austria). The quantification of $\mathrm{Na}, \mathrm{Mg}, \mathrm{Cd}$ and $\mathrm{Pb}$ by ICP-AES was performed selecting the following emission wavelengths: Na $589.6 \mathrm{~nm}$, Mg $280.27 \mathrm{~nm}$, Cd $228.8 \mathrm{~nm}$, and Pb 220.4 nm. The detailed ICP-AES analytical conditions and calibration procedures were previously described. ${ }^{25}$ The analytical accuracy was checked by analysing two standard reference materials: NIST 1573a (tomato leaves) and BCR 679 (white cabbage). The deviation between the experimental data and the certified values for both reference materials was less than $10 \%$ for all the elements analysed both by TXRF and ICP-AES.

\subsection{Analysis of bioactive compounds}

Total chlorophyll content was determined spectrophotometrically using the method of Lichtenthaler and Buschmann ${ }^{26}$ with minor modifications. Excised leaves $(0.5 \mathrm{~g})$ were homogenized and added in $15 \mathrm{~mL}$ acetone (HPLC-UV grade, Pharmco-Aaper, Brookfield, CT, USA) and stirred for $20 \mathrm{~min}$. The mixture was filtered (Grade 413 Filter Paper, Qualitative, VWR International, West Chester, PA, USA) and transferred into spectrophotometric cuvettes. The absorbance was read at $661.6 \mathrm{~nm}$ and $644.8 \mathrm{~nm}$ with a Cary $60 \mathrm{UV}$-VIS system (Agilent Technologies, Santa Clara, PA, USA) and total chlorophyll was calculated as the sum of chlorophyll $a\left(\mathrm{chl}_{a}\right)$ and chlorophyll $b\left(\mathrm{chl}_{b}\right)$ by using the following formulas:

$$
\begin{aligned}
& \operatorname{chl}_{a}\left(\mathrm{mg} \mathrm{L}^{-1}\right)=11.24 A_{661.6}-2.04 A_{644.8} \\
& \operatorname{chl}_{b}\left(\mathrm{mg} \mathrm{L}^{-1}\right)=20.13 A_{644.8}-4.19 A_{661.6}
\end{aligned}
$$

where $A_{n}$ is the absorbance of the extract at $n \mathrm{~nm}$ of wavelength. Four samples were analysed per genotype.

Antiradical activity was evaluated by the 2,2-diphenyl-1picrylhydrazyl (DPPH) stable radical scavenging capacity test, according to Difonzo et $a .^{27}$ The freeze dried samples $(0.1 \mathrm{~g})$ were extracted with $5 \mathrm{~mL}$ methanol : water $(80: 20)$ for 2 hours in tubes covered with aluminum foil. The extracts were then centrifuged for 15 minutes at $15000 \mathrm{~g}$ and $24^{\circ} \mathrm{C}$. The supernatant was recovered and filtered with PTFE septa $(0.45 \mu \mathrm{m})$. The extracts $(50 \mu \mathrm{L})$ were added to $950 \mu \mathrm{L}$ of $0.08 \mathrm{mM} \mathrm{DPPH}$ in methanol. The mixture was shaken and kept at room temperature in the dark for $30 \mathrm{~min}$. The decrease of the absorbance at $517 \mathrm{~nm}$ was measured using a Cary 60 Agilent spectrophotometer (Agilent Technologies, Milan, Italy). The results were expressed in $\mu \mathrm{mol}$ Trolox equivalents (TE) per $100 \mathrm{~g}$ fresh weight. Two samples were analysed per genotype. Each sample was analyzed in triplicate. Total phenolic compounds (TPC) were determined on the same methanolic extract by the FolinCiocalteu assay. ${ }^{28}$ In particular, $100 \mu \mathrm{L}$ of the extract were mixed with $100 \mu \mathrm{L}$ of the Folin-Ciocalteu reagent and, after $4 \mathrm{~min}$, with $800 \mu \mathrm{L}$ of a $5 \%(\mathrm{w} / \mathrm{v})$ solution of sodium carbonate. The mixture was then heated in a water bath at $40{ }^{\circ} \mathrm{C}$ for $20 \mathrm{~min}$ and the total phenol content was determined at $750 \mathrm{~nm}$ by using an Agilent Cary 60 spectrophotometer (Agilent Technologies, Santa Clara, USA). The total phenolic content was expressed as gallic acid equivalents $\left(\mu \mathrm{g} \mathrm{g}^{-1}\right)$.

Total anthocyanins (TA) were extracted by adding $12.5 \mathrm{~mL}$ of $70: 29.5: 0.5(\mathrm{v} / \mathrm{v})$ methanol/water/HCl $(37 \%)$ to $100 \mathrm{mg}$ of the lyophilized sample, and then keeping on an orbital shaker at $500 \mathrm{rpm}$, for $2 \mathrm{~h}$, in the dark. The samples were then centrifuged at $12000 \mathrm{~g}$ for $5 \mathrm{~min}$ and the supernatant was recovered. The absorbance of the solution was determined at $535 \mathrm{~nm}$ by using a Cary 60 UV-Vis spectrophotometer (Agilent Technologies, Santa Clara, CA, USA). A calibration curve was previously set up by using solutions of the standard cyanidin 3-O-glucoside (Phytoplan, Heidelberg, Germany). TA were determined on duplicate samples.

Alpha-tocopherol extraction was performed according to Santos et $a l .{ }^{29}$ The lyophilized sample $(0.250 \mathrm{~g})$ was extracted twice with ethyl acetate containing $0.1 \%$ BHT $(6+6 \mathrm{~mL})$ by agitation for $15 \mathrm{~min}$ and sonication for further $15 \mathrm{~min}$. Finally, the samples were centrifuged $(14000 g, 15 \mathrm{~min})$ and the supernatants combined and filtered through a $0.45 \mu \mathrm{m}$ nylon filter. The extract was taken to dryness under nitrogen and resuspended in $2 \mathrm{~mL}$ of isopropanol. HPLC-FLD analysis was performed using a UHPLC binary system (Dionex Ultimate 3000 RSLC, Waltham, MA, USA). ${ }^{30}$ Isocratic separation was carried out on a C18 column (Acclaim $120 \mathrm{C} 18,150 \mathrm{~mm} \times 4.6 \mathrm{~mm}$, $3 \mu \mathrm{m}$, Thermo Fisher Scientific, Waltham, Massachusetts, USA) with acetonitrile and methanol $(1: 1 \mathrm{v} / \mathrm{v})$ as the mobile phase at a constant flow rate of $1 \mathrm{~mL} \mathrm{~min}^{-1}$. The injection volume was $20 \mathrm{~mL}$. The detection was performed with a fluorescence detector $(\mathrm{exc}=295 \mathrm{~nm}$, em $=325 \mathrm{~nm})$. The quantification of $\alpha$-tocopherol was performed using the external calibration method. Alpha-tocopherol determination was carried out on triplicate samples.

Total carotenoids were determined using Lichtenthaler's formula. ${ }^{26}$ Freeze-dried samples $(0.005 \mathrm{~g})$ were weighed in test tubes, wrapped with aluminium foil, hydrated with $100 \mu \mathrm{L}$ of purified water and extracted in the dark with $8 \mathrm{~mL}$ ethanol. 
The test tubes were incubated at room temperature overnight. Then the samples were vortexed and centrifuged. The absorbance $(A)$ of the extract was measured at $470.0 \mathrm{~nm}, 648.6 \mathrm{~nm}$ and $664.2 \mathrm{~nm}$. Total carotenoids (TC) on a dry weight (DW) basis were determined using the following formula:

$$
\mathrm{TC}=\frac{\left(4.785 \times A_{470}+3.657 \times A_{664.2}+12.76 \times A_{648.6}\right) \times 8.1}{\mathrm{DW}}
$$

where $A_{n}$ is the absorbance of the extract at $n \mathrm{~nm}$ of wavelength. TC were determined on four samples per genotype.

\subsection{Shelf-life evaluation}

The headspace gas composition in the samples was determined using an $\mathrm{O}_{2} / \mathrm{CO}_{2}$ gas analyser (CheckMate II, PBI-Dansensor A/S, Ringsted, DK).

Total chlorophylls were determined as described above.

For the microbiological analysis, replicate samples were pooled to obtain the amounts needed for the analyses. $25 \mathrm{~g}$ of the microgreen samples were placed in a sterile stomacher bag with a polyethylene filter layer containing $225 \mathrm{~mL}$ of buffered peptone water $(0.1 \%$ sterile peptone, w/v) (BPW, Oxoid, CM1049). The samples were homogenized using a Stomacher 400 lab blender (Seward Medical, London, UK) set at $230 \mathrm{rpm}$ for $2 \mathrm{~min}$ and diluted with peptone water for microbial counting. Microbiological analysis was carried out by plating serially diluted samples using different agar media. Total aerobic mesophilic and psychotropic bacteria were enumerated on plate count agar (PCA) and the plates were incubated at $30{ }^{\circ} \mathrm{C}$ for $24-48 \mathrm{~h}$ and $6{ }^{\circ} \mathrm{C}$ for 5-7 days, respectively. Presumptive mesophilic lactobacilli and cocci, Enterobacteriaceae, yeasts and molds were estimated as described previously. ${ }^{31}$ Staphylococci were counted on Baird Parker agar plus egg yolk tellurite (Oxoid), at $37^{\circ} \mathrm{C}$ for $48 \mathrm{~h}$. GSP agar (Fluka, St Louis, MO, USA) plus penicillin-G $\left(60 \mathrm{~g} \mathrm{~L}^{-1}\right)$ was used for Pseudomonas spp. The same pre-enrichment broth was used to detect Salmonella spp. and Escherichia coli, as previously described by Cosmai et al. ${ }^{32}$ Another $25 \mathrm{~g}$ were diluted in $225 \mathrm{ml}$ of listeria enrichment broth base and used for the determination of Listeria monocytogenes as reported by Cosmai et $a l .^{32}$ The media for plating of bacteria were supplemented with cycloheximide at $0.17 \mathrm{~g} \mathrm{~L}^{-1}$. Except for GSP agar, all media were purchased from Oxoid Ltd (Hampshire, UK). Each microbial count was determined as the mean of three measurement results and was expressed as log CFU per g. The microbiological counts were preliminarily confirmed by taking representative colonies for each medium which were analyzed for morphology, motility, Gram staining reaction and catalase test.

Sensory analysis was performed by a trained panel of five judges, experienced with microgreens and fresh cut vegetables. The evaluation of visual quality was performed on a 5-point scale according to Berba and Uchanski ${ }^{33}$ (Table 1).

Olfactive quality, as the appearance of off-odors, was evaluated on a 5 -point scale according to Kou et al. $(1=$ no off-odor and $5=$ extremely strong off-odor). ${ }^{20}$

\subsection{Statistical analysis}

Statistical analysis was carried out using the Minitab 17 software (Minitab Inc., State College, PA, USA). One-way analysis of variance (ANOVA) followed by Tukey's HSD test for multiple comparisons was used to compare the nutritional profiles of the genotypes and for the microbiological data. Two-way ANOVA followed by Tukey's HSD test for multiple comparisons was used for the other shelf-life indices.

\section{Results and discussion}

\subsection{Microgreen yield and proximate composition}

The observed yields for the microgreens ranged from $659 \mathrm{~g} \mathrm{~m}^{-2}$ of BM to $1548 \mathrm{~g} \mathrm{~m}^{-2}$ of CM (Fig. 1). Puglia's local varieties gave the highest (Molfetta, CM) and the lowest (Mugnuli microgreens, BM) yields under the present experimental conditions, pointing out the opportunity to explore the biodiversity heritage to exploit its potential. ${ }^{34}$ However, the data obtained are consistent with the literature data regarding the yields of basil, Swiss chard, rocket and rapini (Brassica oleracea L., Broccoletto group). ${ }^{35,36}$

The proximate composition of the microgreens is reported in Table 2. The dry matter content showed no significant differences among the microgreens $(6.0 \mathrm{~g}$ per $100 \mathrm{~g}$ as an average). Xiao et $a l .^{5,10}$ found slightly higher values (6.9 and $6.6 \mathrm{~g}$ per $100 \mathrm{~g}$ ) for the average dry matter content of 25 and 30 commercial microgreens, respectively, though in some cases,

Table 1 Visual quality rating of microgreens ${ }^{a}$

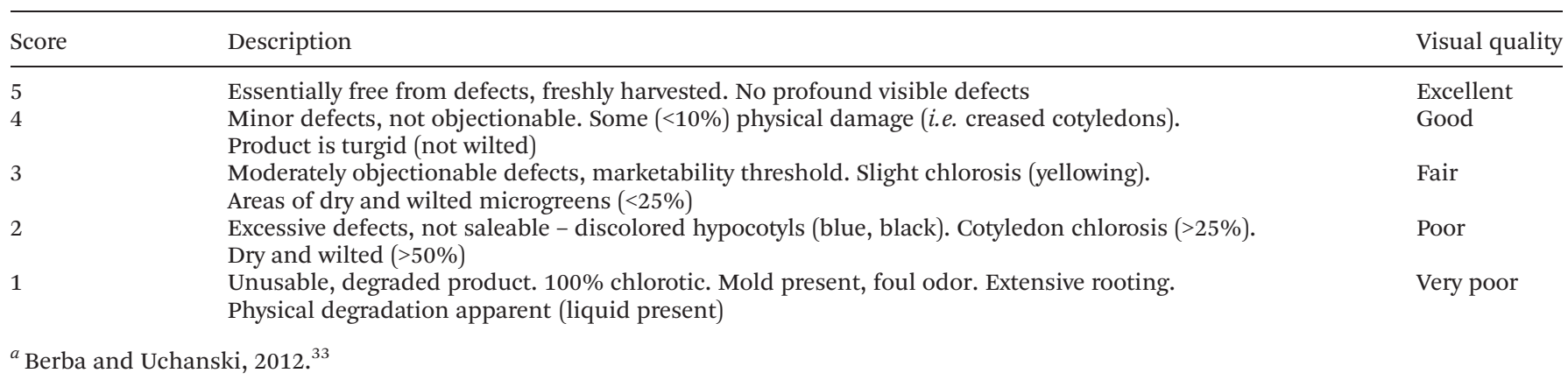




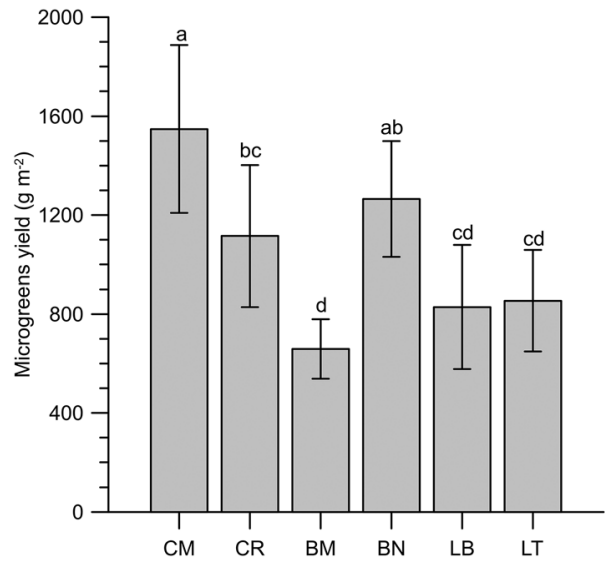

Fig. 1 Yield of microgreens $(n=3)$. Different letters mean a significant difference at $p<0.05$ according to Tukey's HSD test for multiple comparisons. Genotypes: Cichorium intybus L. (Puglia's local variety 'Molfetta', CM, and cultivar 'Italico a costa rossa', CR); Lactuca sativa L. Group crispa (cultivar 'Bionda da taglio', LB, and 'Trocadero', LT); Brassica oleracea L. Group italica Plenk (Puglia's local variety 'Mugnuli', BM, and cultivar 'Natalino', BN).

values above $10 \mathrm{~g}$ per $100 \mathrm{~g}$ were observed. Samuolienè et al. ${ }^{37}$ obtained Brassica microgreens with $5.6 \mathrm{~g}$ per $100 \mathrm{~g}$ dry matter, while basil, Swiss chard and rocket microgreens studied by Bulgari et $a l .{ }^{36}$ showed values in the range of $4.0-5.5 \mathrm{~g}$ per $100 \mathrm{~g}$.

As expected, the lipid content of the microgreens was negligible and comparable to the typical values of traditional leafy vegetables. ${ }^{38}$ Proteins were higher in Brassicaceae than in Asteraceae microgreens. However, their content was not noticeable, reaching a maximum amount of $3.0 \mathrm{~g}$ per $100 \mathrm{~g}$. The microgreens also showed low levels of dietary fibre: the chicory genotypes showed the highest levels, not exceeding $0.70 \mathrm{~g}$ per $100 \mathrm{~g}$. Sugars reached the maximum amount ( $0.80 \mathrm{~g}$ per $100 \mathrm{~g}$ ) in $\mathrm{CR}$ and the minimum level in $\mathrm{BN}(0.19 \mathrm{~g}$ per $100 \mathrm{~g})$. The relatively high fructose content in Asteraceae (particularly chicory) is ascribable to the relevant fructose metabolism shown by these plants. The overall energy value of the micro- greens ranged from $70 \mathrm{~kJ}$ per $100 \mathrm{~g}$ (LB) to $100 \mathrm{~kJ}$ per $100 \mathrm{~g}$ (BM).

\subsection{Mineral content}

The mineral content of the microgreens, expressed on a fresh weight basis, is reported in Table 3 . The most abundant elements in all the samples were, in the order, $\mathrm{K}$ and $\mathrm{Ca}$, followed by $\mathrm{P}$ (in chicory and lettuce microgreens) or $\mathrm{S}$ (in the two Brassica varieties). Recent studies also report that $\mathrm{K}$ is the main element accumulated in the microgreens of Brassicaceae $^{10}$ and lettuce. ${ }^{9}$ The higher $\mathrm{S}$ content of BN and $\mathrm{BM}$, compared to the other microgreens, is ascribable to the presence of S-containing metabolites peculiar to Brassicaceae species, mainly glucosinolate. ${ }^{39} \mathrm{Fe}$ and $\mathrm{Mn}$ were the most prevalent micronutrients (Table 2), in agreement with the outcomes reported by Pinto et al. ${ }^{9}$ The concentrations of $\mathrm{Cd}$ and $\mathrm{Pb}$ in all the samples complied with the safe limits imposed by the EU regulation for leafy vegetables, which amount to 200 and $300 \mu \mathrm{g}$ per $\mathrm{kg} \mathrm{FW}$ for $\mathrm{Cd}$ and $\mathrm{Pb}$, respectively. ${ }^{40}$

The two chicory varieties and LT showed the highest content of $\mathrm{P}, \mathrm{K}, \mathrm{Fe}, \mathrm{Cu}$ and $\mathrm{Ni}$; the concentrations of $\mathrm{P}, \mathrm{K}$ and Fe were similar to those measured by Pinto et al. ${ }^{9}$ in lettuce microgreens. In contrast, LB had the lowest content of mineral elements, except for $\mathrm{Na}$ and $\mathrm{Mn}$, which were the highest in these species and comparable to those reported by Pinto et al. ${ }^{9}$ Both Brassica varieties were noteworthy not only for the highest S concentration, but also for the highest Ca concentration. Their composition reflected that reported by Xiao et $a l .{ }^{10}$ for 30 different Brassicaceae varieties of microgreens, except for the Ca content which exceeded two to five times the literature values. Between the two Brassicaceae genotypes, BN appeared to be the richest in mineral nutrients.

The mineral nutrient profile ( $\mathrm{P}, \mathrm{K}, \mathrm{Ca}, \mathrm{Mg}, \mathrm{Na}, \mathrm{Fe}$ and $\mathrm{Zn}$ ) of the microgreens was compared with the values of the corresponding mature plant, as reported in the National Nutrient Database for Standard Reference of USDA. ${ }^{38}$ Both LB and LT were characterized by contents of $\mathrm{P}, \mathrm{Ca}, \mathrm{Mg}$ and $\mathrm{Zn}$ considerably higher than those reported for mature lettuce butterhead (330 $\mathrm{mg} \mathrm{kg} \mathrm{kg}^{-1} \mathrm{P}, 350 \mathrm{mg} \mathrm{kg} \mathrm{ka}^{-1} \mathrm{Ca}, 130 \mathrm{mg} \mathrm{kg}{ }^{-1} \mathrm{Mg}$, and

Table 2 Proximate composition of microgreens (g per $100 \mathrm{~g} \mathrm{FW)} \mathrm{and} \mathrm{results} \mathrm{of} \mathrm{the} \mathrm{statistical} \mathrm{analysis}{ }^{a}$

\begin{tabular}{|c|c|c|c|c|c|c|c|c|c|c|c|c|c|c|c|c|c|c|}
\hline & \multicolumn{3}{|l|}{$\mathrm{CM}$} & \multicolumn{3}{|l|}{ CR } & \multicolumn{3}{|l|}{$\mathrm{BM}$} & \multicolumn{3}{|l|}{$\mathrm{BN}$} & \multicolumn{3}{|l|}{ LB } & \multicolumn{3}{|l|}{ LT } \\
\hline & Mean & SD & & Mean & SD & & Mean & SD & & Mean & SD & & Mean & SD & & Mean & SD & \\
\hline Lipids & 0.3 & 0.0 & $a b$ & 0.3 & 0.0 & $\mathrm{~b}$ & 0.4 & 0.1 & $\mathrm{a}$ & 0.3 & 0.0 & b & 0.3 & 0.0 & b & 0.3 & 0.1 & $\mathrm{ab}$ \\
\hline Proteins & 1.9 & 0.0 & c & 2.4 & 0.0 & $\mathrm{~b}$ & 3.0 & 0.1 & a & 2.8 & 0.1 & a & 2.6 & 0.1 & $\mathrm{~b}$ & 2.4 & 0.0 & $\mathrm{~b}$ \\
\hline Fibre & 0.62 & 0.07 & $a b$ & 0.70 & 0.06 & $\mathrm{a}$ & 0.36 & 0.03 & c & 0.26 & 0.00 & c & 0.43 & 0.06 & $\mathrm{c}$ & 0.44 & 0.08 & bc \\
\hline Glucose & 0.11 & 0.01 & bc & 0.26 & 0.01 & a & 0.17 & 0.05 & $\mathrm{~b}$ & 0.04 & 0.00 & c & 0.03 & 0.00 & c & 0.17 & 0.00 & $\mathrm{~b}$ \\
\hline Ashes & 0.9 & 0.1 & $\mathrm{~b}$ & 1.1 & 0.2 & $a b$ & 1.2 & 0.1 & a & 1.1 & 0.2 & a & 1.0 & 0.1 & $a b$ & 1.0 & 0.1 & $\mathrm{ab}$ \\
\hline
\end{tabular}

${ }^{a}$ Values are reported as mean \pm standard deviation $(n=3)$. Different letters in the same row indicate a significant difference according to Tukey's test $(P<0.05)$. LOD, limit of detection. Genotypes: Cichorium intybus L. (Puglia's local variety 'Molfetta', CM, and cultivar 'Italico a costa rossa', CR); Lactuca sativa L. Group crispa (cultivar 'Bionda da taglio', LB, and 'Trocadero', LT); Brassica oleracea L. Group italica Plenk (Puglia's local variety 'Mugnuli', BM, and cultivar 'Natalino', BN). 


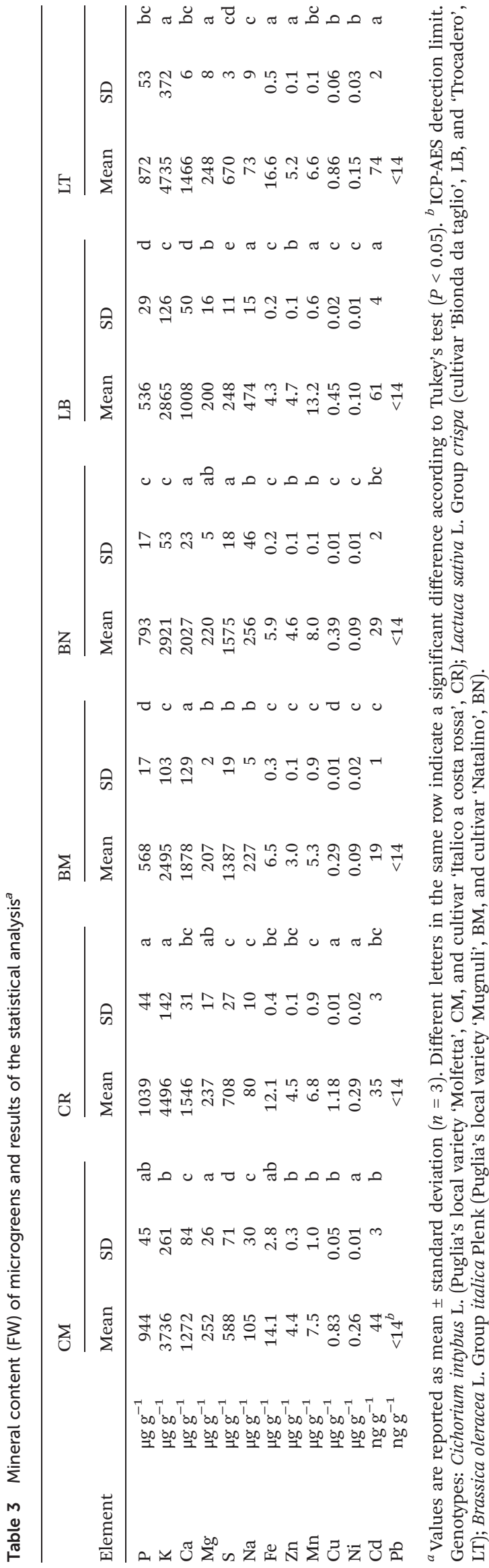

$\left.2 \mathrm{mg} \mathrm{kg}{ }^{-1} \mathrm{Zn}\right)$. Moreover, Bionda lettuce presented a Na concentration about tenfold higher than that reported for mature lettuce, but a lower $\mathrm{Fe}$ content (reference value for $\mathrm{Fe}$ : $12.4 \mathrm{mg} \mathrm{kg}^{-1}$ ). Chicory microgreens showed a higher content of $\mathrm{P}$ and a lower content of $\mathrm{Na}$ compared to mature green chicory (USDA reference value for $\mathrm{P}$ and $\mathrm{Na}: 450 \mathrm{mg} \mathrm{kg}^{-1}$ ). ${ }^{38}$ The mineral composition of $\mathrm{BM}$ and $\mathrm{BN}$ was similar to that of reference mature broccoli, except for Ca which was more abundant in microgreen tissues (reference value: $470 \mathrm{mg} \mathrm{kg}^{-1} \mathrm{Ca}$ ). In general, the microgreens produced under the present experimental conditions resulted in an interesting vegetable source of Ca, K and Mn. According to European Regulations, ${ }^{41,42}$ the microgreens can be considered as sources of the following minerals (i.e. supplying in $100 \mathrm{~g}$ at least $15 \%$ of the nutrient reference value): $\mathrm{K}$ (CM and $\mathrm{LT}$ ) and $\mathrm{Ca}$ (all except LB). Moreover, the relatively high levels of $\mathrm{Mn}$ in all the studied microgreens allow them to be considered as sources of $\mathrm{Mn}$ (BM) or high $\mathrm{Mn}$ foods (being able to provide from $34 \%$ to $66 \%$ of the nutritional reference value). It is noteworthy that Mn can create both problems of dietary deficiency, especially in developing countries, and toxicity, mainly due to environmental pollution and excessive levels in drinking water. ${ }^{43,44}$ The possibility to modulate the mineral contents of microgreens, on the basis of either genetic diversity or agronomic parameters, is being explored, with the aim to provide appropriate supplementation or to reduce dietary exposure to single mineral nutrients. Significant results have been obtained for K, leading to the production of low-K microgreens which could be suitable for patients with impaired kidney function. ${ }^{18}$ Similarly, further research on other mineral elements could aim at producing tailored microgreens with the desired mineral contents.

\subsection{Bioactive compound content}

Chlorophylls, besides being related to freshness and visual quality in leafy vegetable products, ${ }^{45,46}$ have shown significant bioactivity. ${ }^{47,48}$ Chicory (particularly CR) and BN microgreens showed the highest amount of total chlorophylls (703, 601 and $608 \mu \mathrm{g}$ per $\mathrm{g}$ FW for $\mathrm{CR}, \mathrm{CM}$ and $\mathrm{BN}$ respectively), whilst lettuce and BM microgreens contained less than $400 \mu \mathrm{g}$ per $\mathrm{g}$ FW total chlorophylls (Fig. 2A). These levels were in the ranges reported in the literature by other authors for several microgreens: basil, Swiss chard and rocket (771-1007 $\left.\mu \mathrm{g} \mathrm{g}^{-1}\right) ;^{36}$ beet and parsley $\left(280-870 \mu \mathrm{g} \mathrm{g}^{-1}\right) ;^{12}$ and radish $\left(754 \mu \mathrm{g} \mathrm{g}^{-1}\right) .^{22}$ Compared to the literature data on vegetable foods, the microgreens can be considered rich in chlorophylls. ${ }^{45,49-51}$

The antioxidant pattern of the microgreens included hydrophilic phenols, tocopherols and carotenoids. The antiradical activity of methanolic extracts presented the highest levels in the microgreens from Brassicaceae, while the lowest activity was observed in chicory microgreens (Fig. 2B). An analogous outstanding behaviour of Brassicaceae was observed for the total phenolic content (Fig. 2C): $791 \mu \mathrm{g}$ GAE per $\mathrm{g}$ and $655 \mu \mathrm{g}$ GAE per $\mathrm{g}$ were determined in $\mathrm{BN}$ and $\mathrm{BM}$ respectively, while the microgreens from Asteraceae presented halved content of phenolic compounds, ranging from $252 \mu \mathrm{g}$ GAE per $\mathrm{g}$ in CR to 

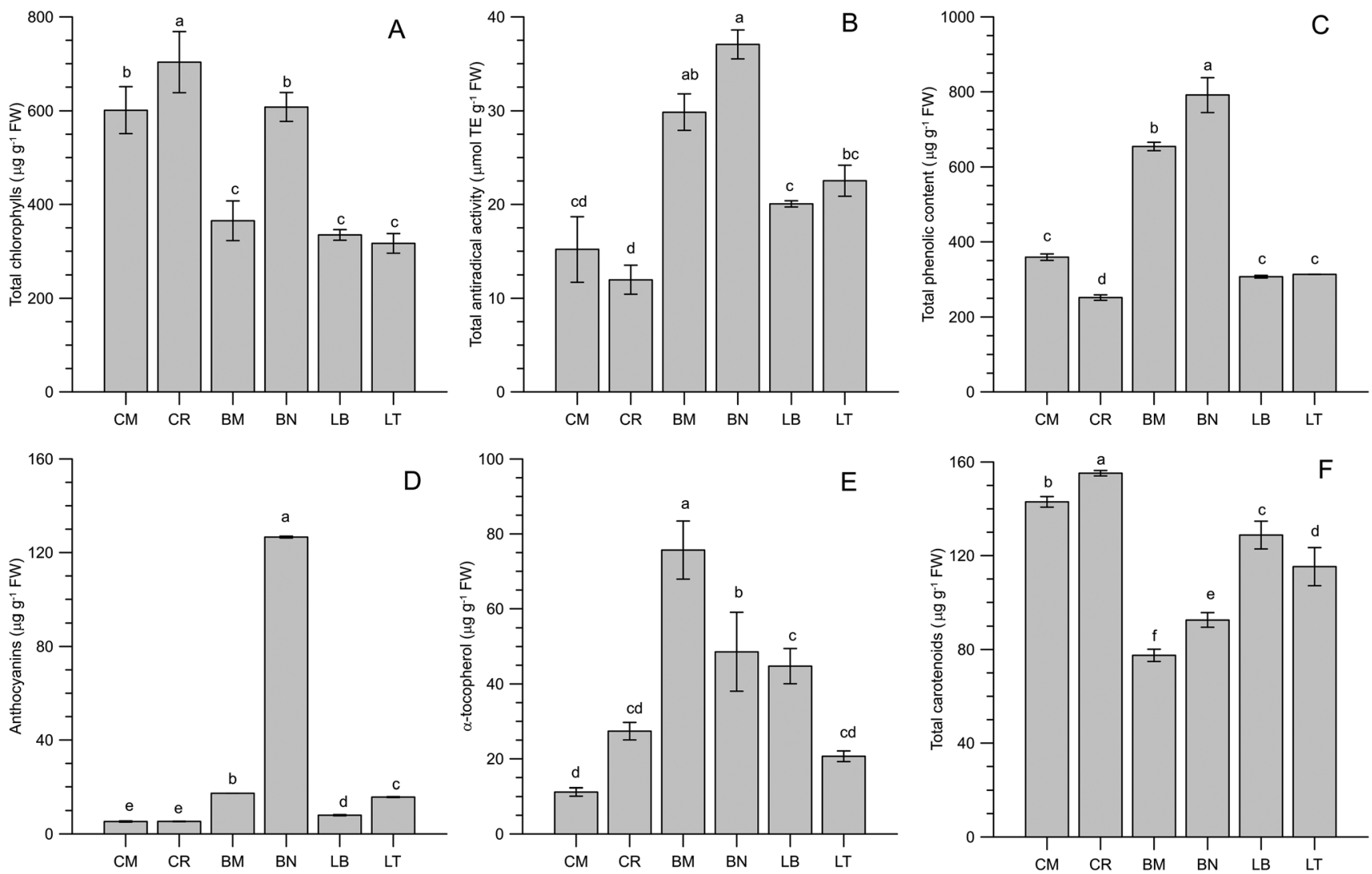

Fig. 2 Bioactive compounds of microgreens. Different letters mean a significant difference at $p<0.05$ according to Tukey's HSD test for multiple comparisons. (A) Total chlorophylls $(n=4)$; (B) total antiradical activity $(n=2)$; (C) total phenolic compounds $(n=2)$; (D) total anthocyanins $(n=2)$; (E) $\alpha$-tocopherol $(n=3)$; and (F) total carotenoids $(n=4)$. Genotypes: Cichorium intybus L. (Puglia's local variety 'Molfetta', CM, and cultivar 'Italico a costa rossa', CR); Lactuca sativa L. Group crispa (cultivar 'Bionda da taglio', LB, and 'Trocadero', LT); Brassica oleracea L. Group italica Plenk (Puglia's local variety 'Mugnuli', BM, and cultivar 'Natalino', BN).

$359 \mu \mathrm{g}$ GAE per $\mathrm{g}$ in CM. Compared to the literature data, the hydrophilic antioxidant activity observed in BN and BM microgreens was quite high. Xiao et al. ${ }^{13}$ reported mean values of about $90 \mu \mathrm{mol}$ TE per $\mathrm{g}$ and $27 \mathrm{mg}$ gallic acid per $\mathrm{g}$ in radish microgreens, but on a dry weight basis. The reported data, expressed on a fresh weight basis, are prevalently included in the range of $0.3-0.6 \mathrm{mg}$ gallic acid per $\mathrm{g}$ in several microgreen species (amaranth, basil, kale, broccoli, mustard, tatsoi, orach, borage, beet, parsley, pea, red pak choi, kohlrabi, Swiss chard and rocket). ${ }^{36,37,52,53}$ In some cases higher phenolic contents were reported, even exceeding $1 \mathrm{mg}$ gallic acid per $\mathrm{g} \mathrm{FW}$, for the same microgreen species (basil, beet, pack choi, mustard, tatsoi and parsley). ${ }^{15,53,54}$ It is interesting to observe that such high phenolic contents were recorded in experiments dealing with artificial lighting systems, pointing out the importance of lighting conditions for the accumulation of photoprotective phenolics since the early stages of plant development. ${ }^{55,56}$ Among the phenolic antioxidants, anthocyanins resulted a significant fraction only in broccoli (BN) microgreens (Fig. 2D). The literature data on anthocyanin contents are quite variable, often reporting several hundreds of $\mu \mathrm{g}$ per $\mathrm{g} F \mathrm{FW},{ }^{15,37}$ though in coloured microgreens (e.g. red pak choi, mustard and kohlrabi). Nevertheless, much lower values (8.83-14.41 $\mu \mathrm{g}$ per $\mathrm{g}$ FW) were observed by Bulgari et al. ${ }^{36}$ in basil, Swiss chard and rocket microgreens. These data were comparable with the other microgreens evaluated in the present study.

Regarding lipophilic antioxidants, $\alpha$-tocopherol was detected in a wide range of concentrations, from 11 to 76 $\mu \mathrm{g}$ per g FW (Fig. 2E). BM microgreens were the richest in this important bioactive compound. Fewer data are available on the $\alpha$-tocopherol content in microgreens. Samuolienè et al. ${ }^{12,53}$ reported values ranging from 0.5 (in beet) to 852 (in parsley) $\mu \mathrm{g}$ per $\mathrm{g} \mathrm{FW}$. Xiao et $a l^{5}{ }^{5}$ reported very high values in commercial microgreens, in the range of 4.9-87.4 g per $100 \mathrm{~g}$ FW in 25 different species. Nevertheless, in a subsequent paper considering six microgreen species, they observed lower values, comparable to those of the present research. ${ }^{57}$ Total carotenoids ranged from less than 80 to almost $160 \mu \mathrm{g}$ per $\mathrm{g}$ FW (Fig. 2F). The microgreens belonging to the Asteraceae family, particularly chicory microgreens, showed the highest contents. These levels were comparable to those reported by other authors, ${ }^{12,36,53,57}$ including commercial microgreens, ${ }^{5}$ though tenfold higher amounts were reported in a recent paper by Brazaityte et $a l .{ }^{54}$ The observed levels of lipophilic compounds were compared to those of the corresponding mature vegetables. ${ }^{38}$ The microgreens showed higher contents of 
$\alpha$-tocopherol compared to mature vegetables. As examples, $\alpha$-tocopherol contents in chicory greens, raw spinach, broccoli and lettuce are, respectively, 22.6, 20.3, 7.8 and $2.2 \mu \mathrm{g} \mathrm{g}^{-1}$. As regards carotenoids, the USDA database (considering the sum of $\beta$-carotene, lutein/zeaxanthin and cryptoxanthin) reports the following contents: $122,103,62$ and $27 \mu \mathrm{g} \mathrm{g}^{-1}$ for raw spinach, chicory greens, lettuce and broccoli respectively. The con- sidered microgreens presented, therefore, increased the contents of carotenoids compared to mature green vegetables.

\subsection{Comprehensive nutritional profile}

Fig. 3 reports a comprehensive nutritional profile of the microgreens. This allows to delineation and rapid comparison of the profile for different microgreens, highlighting the most rele-

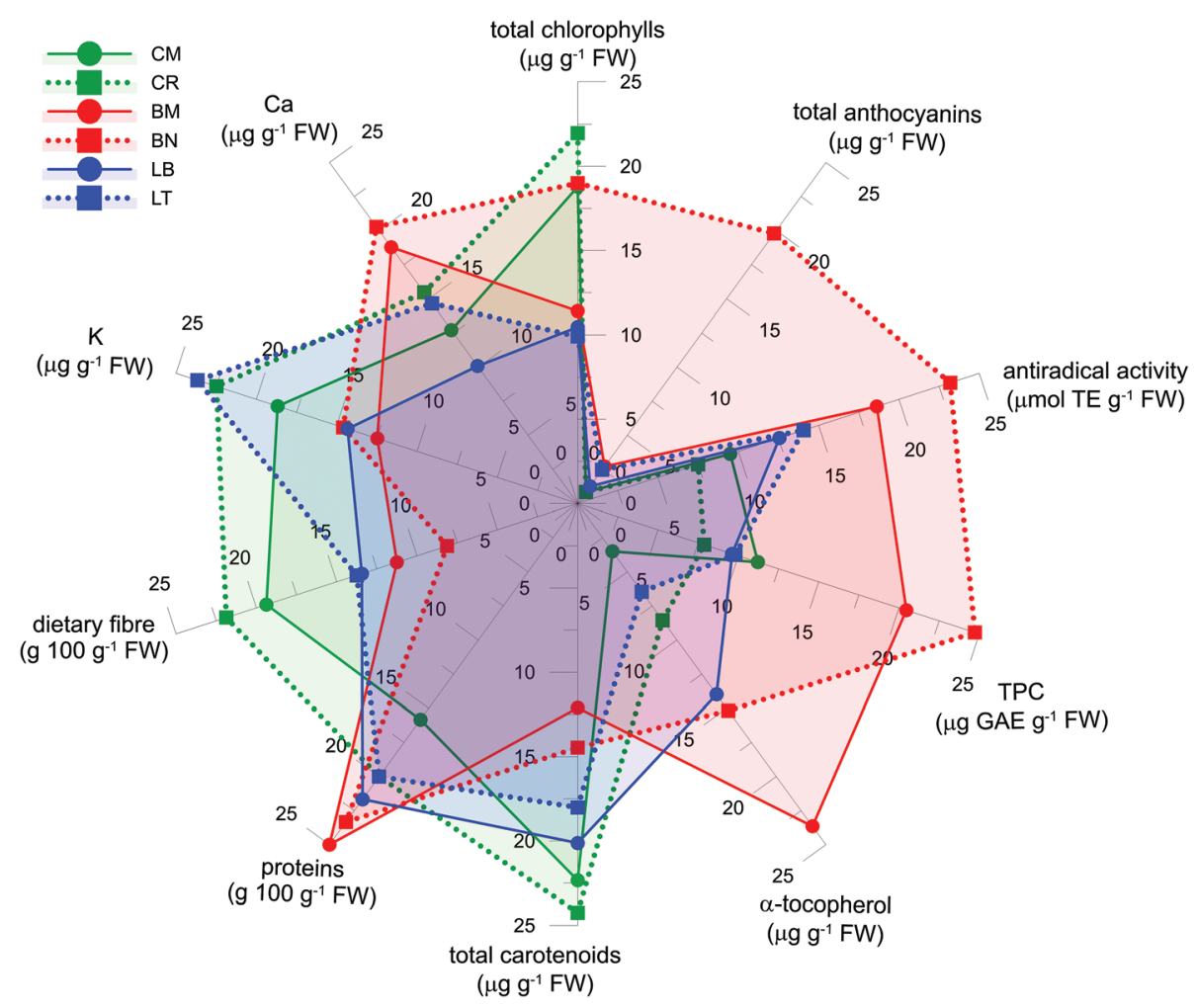

Fig. 3 Nutritional profiles of the six microgreens considered in this study. Genotypes: Cichorium intybus L. (Puglia's local variety 'Molfetta', CM, and cultivar 'Italico a costa rossa', CR); Lactuca sativa L. Group crispa (cultivar 'Bionda da taglio', LB, and 'Trocadero', LT); Brassica oleracea L. Group italica Plenk (Puglia's local variety 'Mugnuli', BM, and cultivar 'Natalino', BN).
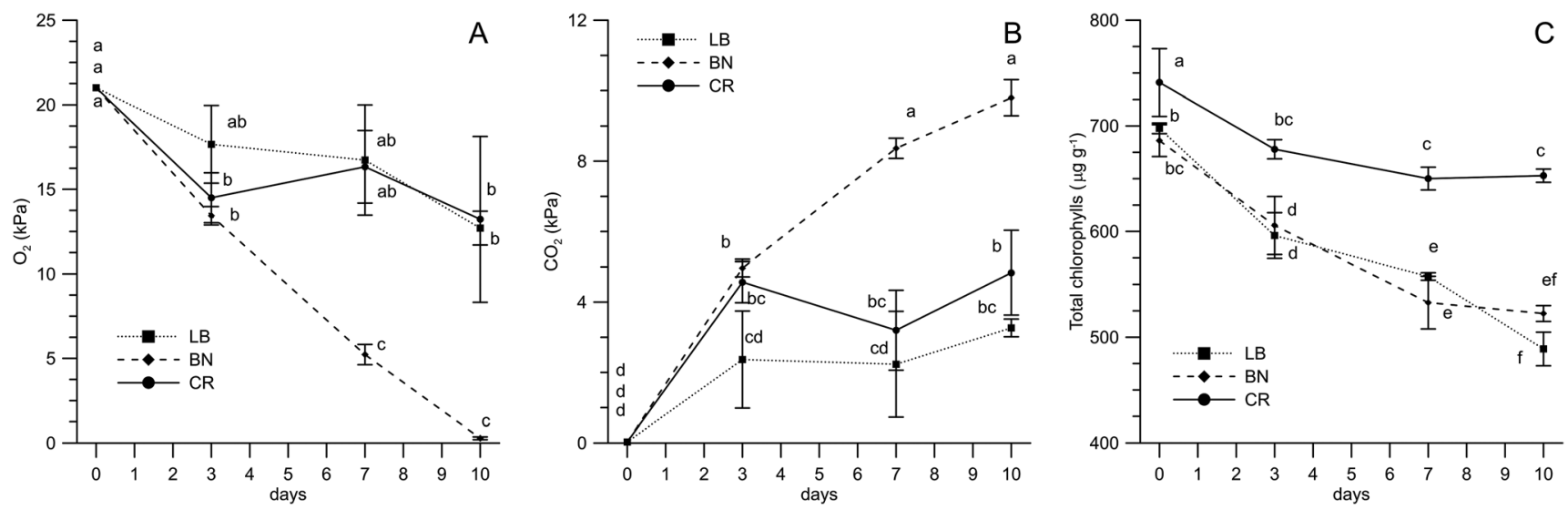

Fig. 4 Storage parameters of fresh cut microgreens packed in polypropylene bags. Different letters mean a significant difference at $p<0.05$ according to Tukey's HSD test for multiple comparisons $(n=3)$. (A) Headspace $\mathrm{O}_{2}$; (B) headspace $\mathrm{CO}_{2}$; and (C) total chlorophylls. Genotypes: Cichorium intybus L. (cultivar 'Italico a costa rossa', CR); Lactuca sativa L. Group crispa (cultivar 'Bionda da taglio', LB); Brassica oleracea L. Group italica Plenk (cultivar 'Natalino', BN). 
vant traits. Nutritional profiles could be useful to appropriately select microgreens on the basis of specific nutritional aspects, and to indicate the directions of further exploitation of the nutritional potential of microgreens. As an example, Brassicaceae microgreens could be considered for the supply of hydrophilic bioactive compounds, $\alpha$-tocopherol and $\mathrm{Ca}$, while Compositae microgreens were valuable for their carotenoid and $\mathrm{K}$ contents. Comprehensive profiling could be considered a step towards the tailored development, selection and use of microgreens.

\subsection{Shelf life}

The shelf-life study was carried out on three microgreens, selected among the six considered for the nutritional characterization, belonging to different species (BN, LB and CR). The choice of the genotypes was made on the basis of various reasons. BN and CR were preferred over BM and CM, respectively, due to the higher yields; LB was preferred over LT for being richer in tocopherols and carotenoids. The analysis of the packaging headspace atmosphere (Fig. $4 \mathrm{~A}$ and B) pointed out a difference between $\mathrm{BN}$ and the microgreens belonging to the Asteraceae family. The respiration of BN microgreens, in fact, led to a linear decrease of the oxygen concentration in the packaging, so that it was $0.3 \mathrm{kPa}$ after 10 days of storage at $5{ }^{\circ} \mathrm{C}$, while $\mathrm{CO}_{2}$ progressively increased up to about $10 \mathrm{kPa}$. In contrast, Asteraceae microgreens reached the equilibrium concentrations of $\mathrm{O}_{2}$ (about $15 \mathrm{kPa}$ ) and $\mathrm{CO}_{2}$ (about $4 \mathrm{kPa}$ ) after three days.

The data available in the literature on respiration rates are mainly regarding fresh cut Brassicaceae microgreens (broccoli, radish and Tah Tasai Chinese cabbage). ${ }^{13,19,20,22}$ The literature confirms high respiration rates of Brassicaceae microgreens, though variations in some packaging parameters (such as total packaging surface) should not be disregarded when comparing the data. As regards headspace gas composition for packed microgreens other than Brassicaceae, only the data regarding buckwheat (Poaceae family) are available ${ }^{23}$ and they report that oxygen reached the equilibrium concentration at about 17 $\mathrm{kPa}$ after four days, with the exception of the bags with the lowest OTR, where $\mathrm{O}_{2}$ pressure decreased for 21 days to a final level of $12 \mathrm{kPa}$.

This points out the need for further information about cultivar/species-related postharvest physiology and, consequently, packaging and shelf-life optimization of fresh-cut microgreens, as previously stated by Kyriacou et al. ${ }^{2}$

Chlorophyll degradation occurs during storage due to senescence processes induced by ethylene ${ }^{58}$ and is related to the visual quality of microgreens. ${ }^{33}$ As expected, all the microgreens underwent chlorophyll degradation (Fig. 4C). In chicory microgreens, however, chlorophylls decreased by about $10 \%$ in the initial phases of storage, remaining unchanged in the final days. LB and BN microgreens, instead, showed a progressive degradation during the entire storage time, with an overall decrease by $20-30 \%$. Similar trends were reported for radish microgreens stored at $5{ }^{\circ} \mathrm{C}$ in polyethylene. ${ }^{22}$

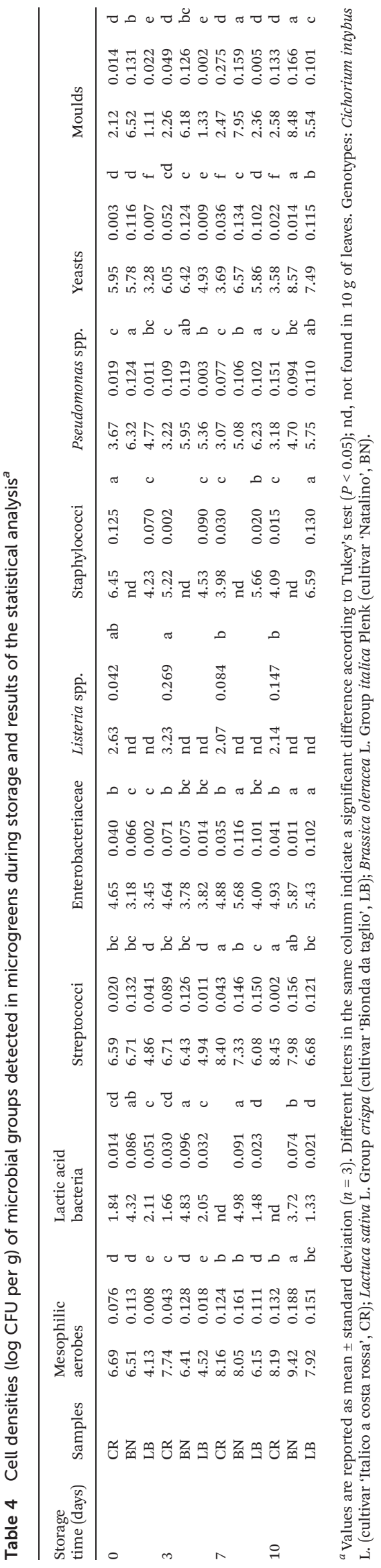


Table 4 shows the microbial population of broccoli, lettuce and chicory microgreens after 1, 3, 7 and 10 days of storage. The number of total aerobic mesophilic bacteria in LB leaves during the initial phase of storage was ca. $4.13 \pm 0.08 \log \mathrm{CFU}$ per $g$, counts lower than those found in the other two types of microgreens. The starting numbers were relatively high, due to the delicate tissues of microgreen stalks that may be more vulnerable to microbes than mature tissues. ${ }^{19,22}$ The data were comparable to or lower than those found for Tah Tasai Chinese cabbage (Brassica campestris var. narinosa), ${ }^{19}$ daikon radish (Raphanus sativus L. var. longipinnatus), ${ }^{22}$ and buckwheat (Fagopyrum esculentum Moench CV. Manner) microgreens. ${ }^{23}$ Instead, the observed final levels observed were comparable to or higher than those reported in the previously cited studies. This may be explained by the differences in the texture of different microgreens and by a "rebound" effect caused in our study by the washing with chlorinated solutions, which is known to cause an immediate decrease of microbial population compared to non-washed products but results in higher microbial numbers during storage. This effect has been attributed to the excess moisture remaining after washing and drying. $^{22,23}$ Psychrotrophic microorganism counts were very similar to those of mesophilic microorganisms (data not shown). The results obtained for BN, LB and CR on microbial cell density agree with those found in the literature for different kinds of vegetables. The highest cell density of lactic acid bacteria (LAB) was detected in $\mathrm{BN}$ and this microbial population decreased by $1 \log$ cycle in ten days. LAB have been reported in a wide variety of vegetables with cell density ranging from 2 to $8 \mathrm{log} \mathrm{CFU}$ per $\mathrm{g} .{ }^{59}$ Streptococci were in the range of 4.86-6.71 $\log \mathrm{CFU}$ per $\mathrm{g}$ at day 1 and storage led to gradual increases of about 1-2 log cycles for all types of microgreens after ten days. Refrigeration brought about a rise in Enterobacteriaceae counts of $2 \log$ CFU per $g$ in $\mathrm{BN}$ and $\mathrm{LB}$, after 10 days of storage. Enterobacteriaceae are considered as a hygiene indicator. However, their presence does not indicate the presence of pathogenic microorganisms. ${ }^{60}$ Biochemical and serological tests on Salmonella spp. excluded the presence of the pathogen, in agreement with the requirements of the EC Regulation No 2073/2005 on microbiological criteria for foodstuffs. E. coli cell density was below the limit indicated in the abovementioned EC Regulation (100 CFU per g) (data not shown). None of the isolates was identified as E. coli $\mathrm{O} 157: \mathrm{H7}$.
Previous studies by Xiao et al. ${ }^{61}$ indicated that $E$. coli strains could significantly proliferate during microgreen growth, reaching different levels depending on the initial inoculation level of the seeds. Oh et al. ${ }^{62}$ evaluated the microbiological quality of Brassica campestris var. narinosa microgreen and reported that the contamination level of coliforms was $3.2 \mathrm{log}$ CFU per g, while Salmonella spp., Listeria monocytogenes, and pathogenic $E$. coli were not detected. The viable numbers of Pseudomonas spp. present in broccoli leaves were ca. $6.3 \mathrm{log}$ CFU per $g$ and decreased by 2 log CFU per $g$ until the end of storage. Both Pseudomonas and LAB are normal microbiota of vegetables, whereas coliforms, yeasts and molds may arise from the raw material or from contamination during processing. ${ }^{63}$ Listeria spp. were found only in chicory, with cell density in the range of 2.14-3.23 log CFU per g. Biochemical and serological tests on L. monocytogenes allow exclusion of the presence of this species. Molds and yeasts reached 8.5-5.5 and 8.6-7.5 log CFU per $\mathrm{g}$ in $\mathrm{BN}$ and $\mathrm{LB}$, respectively, at the end of storage. Tournas ${ }^{64}$ found similar results with fresh and minimally-processed vegetables, and sprouts. The lowest cell densities for molds and yeasts were found in CR samples, and remained unchanged in ten days of storage. Badosa et al. ${ }^{65}$ reported yeast and mold counts in most of the vegetable samples, ranging from 4 to $7 \log$ CFU per g.

Sensory evaluation gave results related to the different metabolic activities observed in the packed microgreens (Table 5). Broccoli microgreens were the first to undergo sensory deterioration due to the higher respiratory activity and mould number compared to other microgreens. Visual quality showed some defects after three days, though remaining acceptable. The other microgreens were unchanged at that time. After one week, the olfactive properties of LB were still optimal, while all other sensory scores pointed out the presence of visual and olfactive defects. However, sensory quality was still satisfactory. After ten days of storage, the three microgreens differed substantially. BN received the lowest score for both visual and olfactive quality. CR was in better conditions, though being below the marketability threshold. LB microgreens, instead, showed only moderately objectionable defects and were still above the marketability threshold.

A sensory shelf-life extension of fresh-cut broccoli microgreens up to 21 days was obtained by other authors using preharvest treatments with calcium salts. ${ }^{14,20,21}$ Kou et al. also

Table 5 Sensory scores of packed microgreens during storage at $5^{\circ} \mathrm{C}$

\begin{tabular}{|c|c|c|c|c|c|c|}
\hline \multirow[b]{2}{*}{ Storage time (days) } & \multicolumn{2}{|l|}{$\mathrm{CR}$} & \multicolumn{2}{|l|}{$\mathrm{BN}$} & \multicolumn{2}{|l|}{ LB } \\
\hline & Visual & Olfactive & Visual & Olfactive & Visual & Olfactive \\
\hline 0 & 5 & 5 & 5 & 5 & 5 & 5 \\
\hline 3 & 5 & 5 & 4 & 5 & 5 & 5 \\
\hline 7 & 4 & 4 & 4 & 4 & 4 & 5 \\
\hline 10 & 2 & 2 & 1 & 1 & 3 & 3 \\
\hline
\end{tabular}

Genotypes: Cichorium intybus L. (cultivar 'Italico a costa rossa', CR); Lactuca sativa L. Group crispa (cultivar 'Bionda da taglio', LB); Brassica oleracea L. Group italica Plenk (cultivar 'Natalino', BN). 
showed that post-harvest treated microgreens presented shorter shelf-lives, from the sensory point of view, compared to pre-harvest ones, and that broccoli microgreens washed with chlorine hardly remained acceptable up to 11 days. $^{21}$ Chandra et al. ${ }^{19}$ reported that off-odors in fresh-cut Tah Tasai cabbage microgreens, treated with chlorine, remained tolerable for seven days. The authors obtained an extension to nine days with sanitizers other than chlorine. Xiao et al. ${ }^{13}$ reported that the sensory acceptability of fresh-cut radish microgreens ranged from less than 8 days to 16 days, depending on the packaging material and exposure to light/darkness. No data are available in the literature on microgreens belonging to families other than Brassicaceae.

\section{Conclusions}

Microgreens are an emerging class of specialty crops that have gained increasing attention in the last decade for both their nutritional and organoleptic traits. In the present study, for the first time, a comprehensive nutritional profile, including proximate composition, was evaluated for some cultivars and local varieties of microgreens grown by using an ad hoc cultivation protocol.

Interesting properties were highlighted for the studied genotypes as compared with their mature leaf counterparts, mainly regarding mineral nutrients ( $\mathrm{Ca}$ and $\mathrm{K}$, above all) and the content of some bioactive compounds (such as carotenoids and $\alpha$-tocopherol). These results suggest the possibility to delineate genotype-specific nutritional profiles, also to further exploit the quality potential of microgreens. In this regard, biodiversity, combined with appropriate growing techniques, could be a precious resource for developing tailored microgreens, with the desired nutritional features.

On the other hand, the high perishability of fresh cut microgreens shown in this study poses the need for appropriate approaches aimed at preserving as long as possible their post-harvest nutritional and organoleptic value.

\section{Conflicts of interest}

There are no conflicts of interest to declare.

\section{Acknowledgements}

This work was funded by the Fondazione Puglia [Bando Ricercatori 2015 - project "Caratterizzazione nutrizionale e shelf-life di micro-ortaggi confezionati - Nutritional characterization and shelf-life of packaged microgreens"].

\section{References}

1 M. Renna, F. Di Gioia, B. Leoni, C. Mininni and P. Santamaria, J. Culin. Sci. Technol., 2017, 15, 126-142.
2 M. C. Kyriacou, Y. Rouphael, F. Di Gioia, A. Kyratzis, F. Serio, M. Renna, S. De Pascale and P. Santamaria, Trends Food Sci. Technol., 2016, 57, 103-115.

3 F. Di Gioia and P. Santamaria, Microgreens - Novel fresh and functional food to explore all the value of biodiversity, ECOlogica srl, Bari, 2015.

4 F. Di Gioia, M. Renna and P. Santamaria, in Minimally Processed Refrigerated Fruits and Vegetables, ed. F. Yildiz and R. C. Wiley, Springer US, Boston, MA, 2017, pp. 403-432.

5 Z. Xiao, G. E. Lester, Y. Luo and Q. Wang, J. Agric. Food Chem., 2012, 60, 7644-7651.

6 D. D. Treadwell, R. Hochmuth, L. Landrum and W. Laughlin, Univ. Florida IFAS Ext., HS1164, 2010, 1-3.

7 J. Sun, Z. Xiao, L. Lin, G. E. Lester, Q. Wang, J. M. Harnly and P. Chen, J. Agric. Food Chem., 2013, 61, 10960-10970.

8 S. A. Mir, M. A. Shah and M. M. Mir, Crit. Rev. Food Sci. Nutr., 2017, 57, 2730-2736.

9 E. Pinto, A. A. Almeida, A. A. Aguiar and I. M. P. L. V. O. Ferreira, J. Food Compos. Anal., 2015, 37, 38-43.

10 Z. Xiao, E. E. Codling, Y. Luo, X. Nou, G. E. Lester and Q. Wang, J. Food Compos. Anal., 2016, 49, 87-93.

11 A. Brazaitytè, S. Sakalauskienè, G. Samuolienè, J. Jankauskienė, A. Viršilè, A. Novičkovas, R. Sirtautas, J. Miliauskienè, V. Vaštakaitè, L. Dabašinskas and P. Duchovskis, Food Chem., 2015, 173, 600-606.

12 G. Samuolienè, A. Viršilè, A. Brazaitytè, J. Jankauskienè, S. Sakalauskienè, V. Vaštakaitė, A. Novičkovas, A. Viškelienè, A. Sasnauskas and P. Duchovskis, Food Chem., 2017, 228, 50-56.

13 Z. Xiao, G. E. Lester, Y. Luo, Z. Xie, L. Yu and Q. Wang, Food Chem., 2014, 151, 472-479.

14 Y. Lu, W. Dong, J. Alcazar, T. Yang, Y. Luo, Q. Wang and P. Chen, J. Food Compos. Anal., 2018, 67, 55-62.

15 V. Vaštakaite, A. Viršile, A. Brazaityte, G. Samuoliene, J. Jankauskiene, A. Novičkovas and P. Duchovskis, J. Agric. Food Chem., 2017, 65, 6529-6534.

16 J. J. van den Driessche, J. Plat and R. P. Mensink, Food Funct., 2018, 9, 1944-1966.

17 M. C. Kyriacou, S. De Pascale, A. Kyratzis and Y. Rouphael, Front. Plant Sci., 2017, 8, 8-11.

18 M. Renna, M. Castellino, B. Leoni, V. Paradiso and P. Santamaria, Nutrients, 2018, 10, 675.

19 D. Chandra, J. G. Kim and Y. P. Kim, Hortic., Environ. Biotechnol., 2012, 53, 32-40.

20 L. Kou, T. Yang, Y. Luo, X. Liu, L. Huang and E. Codling, Postharvest Biol. Technol., 2014, 87, 70-78.

21 L. Kou, T. Yang, X. Liu and Y. Luo, HortScience, 2015, 50, 1801-1808.

22 Z. Xiao, Y. Luo, G. E. Lester, L. Kou, T. Yang and Q. Wang, LWT-Food Sci. Technol., 2014, 55, 551-558.

23 L. Kou, Y. Luo, T. Yang, Z. Xiao, E. R. Turner, G. E. Lester, Q. Wang and M. J. Camp, LWT-Food Sci. Technol., 2013, 51, 73-78.

24 Official Methods of Analysis of AOAC INTERNATIONAL, ed. W. Horwitz and G. W. Latimer, AOAC INTERNATIONAL, Gaithersburg, MD, USA, 18th edn, 2005. 
25 C. E. Gattullo, C. Mininni, A. Parente, F. F. Montesano, I. Allegretta and R. Terzano, Environ. Sci. Pollut. Res., 2017, 24, 25406-25415.

26 H. K. Lichtenthaler and C. Buschmann, in Current Protocols in Food Analytical Chemistry, John Wiley \& Sons, Inc., Hoboken, NJ, USA, 2001, vol. 2-2, pp. 171-178.

27 G. Difonzo, A. Russo, A. Trani, V. M. Paradiso, M. Ranieri, A. Pasqualone, C. Summo, G. Tamma, R. Silletti and F. Caponio, J. Funct. Foods, 2017, 31, 63-70.

28 V. M. Paradiso, A. Clemente, C. Summo, A. Pasqualone and F. Caponio, Food Chem., 2016, 212, 43-47.

29 J. Santos, J. A. Mendiola, M. B. P. P. Oliveira, E. Ibáñez and M. Herrero, J. Chromatogr. A, 2012, 1261, 179-188.

30 A. Tamborrino, G. Squeo, A. Leone, V. M. Paradiso, R. Romaniello, C. Summo, A. Pasqualone, P. Catalano, B. Bianchi and F. Caponio, J. Food Eng., 2017, 205, 34-46.

31 M. Calasso, L. Mancini, R. Di Cagno, G. Cardinali and M. Gobbetti, J. Dairy Sci., 2015, 98, 5874-5889.

32 L. Cosmai, F. Caponio, C. Summo, V. M. Paradiso, A. Cassone and A. Pasqualone, Ital. J. Food Sci., 2017, 29, 302-316.

33 K. Berba and M. Uchanski, J. Young Investig., 2012, 24, 1-5.

34 A. Elia and P. Santamaria, Ital. J. Agron., 2013, 8, 21-34.

35 F. Di Gioia, P. De Bellis, C. Mininni, P. Santamaria and F. Serio, J. Sci. Food Agric., 2017, 97, 1212-1219.

36 R. Bulgari, A. Baldi, A. Ferrante and A. Lenzi, N. Z. J. Crop Hortic. Sci., 2017, 45, 119-129.

37 G. Samuolienè, A. Brazaitytè, J. Jankauskienè, A. Viršilè, R. Sirtautas, A. Novičkovas, S. Sakalauskienè, J. Sakalauskaitė and P. Duchovskis, Cent. Eur. J. Biol., 2013, 8, 1241-1249.

38 USDA, Food Composition Databases, https://ndb.nal.usda. gov/ndb/nutrients/index, (accessed 17 April 2018).

39 J. W. Fahey, A. T. Zalcmann and P. Talalay, Phytochemistry, 2001, 56, 5-51.

40 Regulation (EC) No 1881/2006, Official Journal of the European Union, 2006.

41 Regulation (EC) No 1924/2006, Official Journal of the European Union, 2006.

42 Regulation (EU) No 1169/2011, Official Journal of the European Union, 2011.

43 J. H. Freeland-Graves, T. Y. Mousa and S. Kim, J. Trace Elem. Med. Biol., 2016, 38, 24-32.

44 X. Cai, X. Chen, N. Yin, H. Du, G. Sun, L. Wang, Y. Xu, Y. Chen and Y. Cui, Food Funct., 2017, 8, 4592-4600.
45 M. V. Agüero, M. V. Barg, A. Yommi, A. Camelo and S. I. Roura, J. Food Sci., 2007, 73, S47-S55.

46 D. Žnidarčič, D. Ban and H. Šircelj, Food Chem., 2011, 129, 1164-1168.

47 M. G. Ferruzzi and J. Blakeslee, Nutr. Res., 2007, 27, 1-12.

48 C. Y. Hsu, Y. H. Chen, P. Y. Chao, C. M. Chen, L. L. Hsieh and S. P. Hu, Mutat. Res., Genet. Toxicol. Environ. Mutagen., 2008, 657, 98-104.

49 T. Bohn and T. Walczyk, J. Chromatogr. A, 2004, 1024, 123-128.

50 A. Ferrante and T. Maggiore, Postharvest Biol. Technol., 2007, 45, 73-80.

51 H.-D. Belitz, W. Grosch and P. Schieberle, Food chemistry, Springer, 2009.

52 G. Samuolienè, A. Brazaitytè, R. Sirtautas, S. Sakalauskienè, J. Jankauskienè, P. Duchovskis and A. Novičkovas, Acta Hortic., 2012, 649-656.

53 G. Samuolienè, A. Brazaitytè, A. Viršilè, J. Jankauskienè, S. Sakalauskienè and P. Duchovskis, PLoS One, 2016, 11, e0163405.

54 A. Brazaitytè, S. Sakalauskienè, G. Samuolienè, J. Jankauskienė, A. Viršilè, A. Novičkovas, R. Sirtautas, J. Miliauskienė, V. Vaštakaitė, L. Dabašinskas and P. Duchovskis, Food Chem., 2015, 173, 600-606.

55 K. H. Son and M. M. Oh, HortScience, 2013, 48, 988-995.

56 E. Y. Kim, S. A. Park, B. J. Park, Y. Lee and M. M. Oh, Hortic., Environ. Biotechnol., 2014, 55, 506-513.

57 Z. Xiao, G. E. Lester, E. Park, R. A. Saftner, Y. Luo and Q. Wang, Postharvest Biol. Technol., 2015, 110, 140-148.

58 J. W. Heaton and A. G. Marangoni, Trends Food Sci. Technol., 1996, 7, 8-15.

59 P. Ragaert, F. Devlieghere and J. Debevere, Postharvest Biol. Technol., 2007, 44, 185-194.

60 K. Nguz, J. Shindano, S. Samapundo and A. Huyghebaert, Food Control, 2005, 16, 623-628.

61 Z. Xiao, G. Bauchan, L. Nichols-Russell, Y. Luo, Q. Wang and X. Nou, J. Food Prot., 2015, 78, 1785-1790.

62 T. Y. Oh, S. Y. Baek, J. H. Choi, M. C. Jeong, O. K. Koo, S. M. Kim and H. J. Kim, J. Appl. Biol. Chem., 2016, 59, 63-68.

63 C. Nguyen-the and F. Carlin, Crit. Rev. Food Sci. Nutr., 1994, 34, 371-401.

64 V. H. Tournas, Int. J. Food Microbiol., 2005, 99, 71-77.

65 E. Badosa, R. Trias, D. Parés, M. Pla and E. Montesinos, J. Sci. Food Agric., 2008, 88, 605-611. 